\title{
The role of information and knowledge in achieving environmentally sound farming: a Chinese case
}

Geir Inge Orderud, (corresponding author)

Norwegian Institute of Urban and Regional Research, Oslo and Akershus University College of Applied Sciences.

P.O. Box 4 St. Hanshaugen, N-0130, Oslo, Norway

(+47 46447084 cell phone)

E-mail: geir.orderud@nibr.no

Rolf D. Vogt

Department of Chemistry, University of Oslo

P.O. Box 1033 Blindern, N-0315 Oslo, Norway

(+47 22855696 office phone) (+47 90615415 cell phone)

E-mail: r.d.vogt@kjemi.uio.no

Hongze Tan

Department of Public Policy, City University of Hong Kong

Tat Chee Avenue, Kowloon, Hong Kong SAR

(+852 67000802 cell phone)

E-mail: hongzetan2-c@my.cityu.edu.hk

Jing Luo

Institute of Chinese Borderland Research

Chinese Academy of Social Science

No. 10 Xianxiao HuTong, Dongcheng District, Beijing China 100005

(+86 13810880345 cell phone)

E-mail: 1jing25@163.com 
Abstract:

The article analyzes the role of information-knowledge for making farming environmentally friendly, using eutrophication of the main drinking water reservoir of Tianjin city as a case. The analysis considers information and instruction sources used by farmers in relation to their farming and environmental issues, in particular application of fertilizers, and on this basis it is discussing governance and policy measures. The study is interdisciplinary, covering both natural and social science, and it is based on quantitative methodology, employing descriptive and multivariate statistical methods.

The main findings are: (i) Farmers make use of a broad range of information and instruction sources, thereby confirming the claim that eutrophication and hence good farming practices is a "wicked" problem; (ii) The young and the members of the Communist party are more active than other in using a broad range of information and instruction sources; (iii) Different categories of farmers give priority to different information and instruction sources, providing a basis for tailor-made disseminations; (iv) The majority of farmers report receiving clear instructions for using fertilizers, yet half of them conceive using fertilizers correctly as difficult; (v) Receiving instructions from other farmers and suppliers cater for high scores on clear instructions; and (vi) Farmers are best seen as muddling through different pressures from above and different knowledge bases, and not just willy-nilly responding to top-down policy instructions.

Keywords:

Environmental behavior - information network - eutrophication - farming - China 


\section{Introduction}

China is grappling with deteriorating water quality, especially in the water scarce and densely populated lowland of northeast China. The monsoon rain aggravates this problem by flushing pollutants ${ }^{1}$ into watercourse systems, ending many places up in drinking water reservoirs (Zhou et al. 2014). Fluxes of nutrients are part of such flushes, leading to eutrophication, fueling algae growth and causing inferior water quality for people, as well as an impoverished biodiversity. This ruining of scarce water resources has brought water pollution to the top of the political priority ladder (Huang et al. 2010), resulting in new and amended laws targeting water pollution ${ }^{2}$.

Through the years environmental studies have taken different approaches for analyzing and deducing the best measures for coping with pollution issues like this. The Information deficit model was an early approach, based on the idea that information, awareness, learning, and (scientific) knowledge ${ }^{3}$ about the brute fact of environmental degradation will facilitate actions mitigating and abating the ills. Academically, this model has been criticized by scholars of other approaches, e.g. ecological economics, environmental behavior, and political ecology, arguing that it is making communication just cognitive, ignoring ethical and political considerations, thereby excluding participatory processes (e.g. Barr 2008; Burgess, Harrison, and Filius 1998; Gross 1994; Owens 2000). However, the importance of providing (sciencebased) information (i.e. the core message of the Information deficit model) has continued to play an important role as part of knowledge based policy-making (e.g. Owens 2000; Scholz 2011).

Within the research field of Environmental behavior, the changing role of information became manifested by the work of Kollmuss and Agyeman (2002) and Barr (2007, 2008), with 
information becoming inherent to knowledge and experience. Although not being discarded, information-knowledge has to a certain extent been devalued, becoming just one among several factors. However, along with the concurrent rise of the network society, flows of information within informational structures have become decisive for the functioning of modern societies (e.g. Castells 1996, 2010). Therefore, conducting analyses on the role of information-knowledge in taking actions against environmental pollution merits renewed attention. Moreover, a previous study on the same sample of farmers as this study (Orderud et al. 2015) found that "having received instructions in the use of Phosphorus" as a fertilizer as well as a cause for eutrophication was one of the variables explaining why farmers were taking environmental actions, whereas having correct "knowledge on Phosphorus" did not appear as explanatory. This spurred us to look more closely into the role of informationknowledge in doing farming.

Responding to the above, we analyze the role of information-knowledge within the framework of Barr's $(2007,2008)$ three categories of environmental values, situational factors, and psychological factors, after separating information-knowledge from situational factors. Commonly, the role of information-knowledge has been studied by assessing whether and how well locals comply with top-down information campaigns. In a similar vein, China is conventionally seen as a top-down and hierarchical governed system, with information flowing from the top down to the local. Recent research has modified this, elaborating the perspective put forward by Lieberthal and Oksenberg (1988) of fragmented authoritarianism (Mertha 2008), or coining new terms as e.g. adaptive governance (Heilmann and Perry 2011); project governance (Qu 2012); and consultative authoritarianism (Teets 2013), indicating that local agents like county governments can play an active role in policy design. Moreover, 
Zhou et al. (2013) found Lindblom's (1959) term “muddling through" as more instructive than the top-down inspired term of "tournament", with the latter denoting a system with local actors just responding to incentives when describing implementation of environmental policies at the local level. The "muddling through" indicates interaction and possibly a balancing of different interests. This literature merits a focus on what happens at local scales because it opens for local agency based on information from different sources.

Taking a grass-root perspective, focusing on the structure of information-knowledge among farmers, this study is filling a gap in the literature by analyzing and enhancing our understanding of the basis for local agro-ecological practices determining diffuse runoff of nutrients and subsequently how serious the eutrophication in the recipient turns out to be. Furthermore, analyzing farmers and eutrophication through an interdisciplinary social-natural science perspective, the study takes into account farmers' close relations with the natural environment.

The study case is the watershed of the Yuqiao raw water reservoir, situated at the outskirt of the Beijing-Tianjin city conurbation, providing drinking water for some six million residents of Tianjin megacity. The reservoir is experiencing degrading water quality due to eutrophication, and the watershed is, as described in detail in Zhou (2016), generic for this part of China, a region that is strongly influenced by agricultural activities. Livestock ${ }^{4}$ dung accounts for 52 percent, mineral fertilizers 33 percent, and human sewage 15 percent of the nutrients ending up in the water reservoir (Gu, Luo, and Orderud 2015).

The main aims of the study are:

(i) Assess farmer's use of information on farming and environmental issues, and specifically the use of instructions sources for applying fertilizers. 
(ii) Analyze how the use of different types of information and instruction sources influence the farmers' opinions in regards to their use of fertilizers.

Section 2 presents the theoretical background of the study and section 3 the case study and the quantitative method. Section 4 comprises the statistical analysis with findings answering the two first research questions. In section 5 findings are discussed and here we also discuss governance issues related to our findings.

\section{Theory and hypotheses}

\section{Theory}

As stated above, the study is situated within the field of Environmental behavior theory by applying a modified version of the approach outlined by Barr $(2007,2008)$ for analyzing networks of information-knowledge in farming. In doing this, the study also is focusing on learning processes of the agro-environmental nexus, thereby explicitly building on theories of learning. Central in this respect is the claim that the increasing complexity of curbing, mitigating, and abating adverse environmental conditions, especially in relation to climate change, is favoring social learning; that is, iterative reflections within groups facilitated by shared ideas and experiences with others (e.g. Ison, Röling, and Watson. 2007; Pahl-Wostl 2009). The two other types of learning, experiential learning (learning-by-doing) and transformative learning (instrumental task-oriented learning and communicative learning) are alone considered insufficient for the tasks of tackling challenges of the magnitude of climate change. Reviewing the understanding of social learning, Reed et al. (2010) concluded that a change in individuals' understanding must have taken place, and that learning must go beyond the individual, becoming part of wider social units or communities. 
Eutrophication may appear as a simpler socio-environmental challenge than climate change, but has nevertheless been found to be more problematic to deal with than previously anticipated. Several authors have termed eutrophication caused by nutrient fluxes from nonpoint agricultural sources as a 'wicked problem' (e.g. Smith and Porter 2010; Patterson, Smith, and Bellamy 2013) because it "is highly multi-actor, multi-scalar, dynamic, uncertain, and unclear" (Patterson, Smith, and Bellamy 2013, 442) and with social and institutional dimensions not well understood. It appears that all three types of learning are part-and-parcel in order to acquire the knowledge base required for taking appropriate actions (Orderud and Winsvold 2012) against eutrophication. In other words, asking for social learning implies addressing experiential and transformative learning. This means that the information needed for generating adequate environmental literacy will have to run in many directions, encompassing different actors in order to establish a common ground for taking actions. This is not plain sailing. Science does not provide any unequivocal message and conflicting interests show up; e.g. upstream versus downstream as well as crop yield versus water quality.

Commonly, policies abating diffuse runoff of nutrients from agriculture seek to change farming practice, reducing the amount of total phosphorus that is lost to surface waters. In order to understand how this is conceived we need to consider the role played by tacit knowledge: understanding nature means interiorizing it and 'to know that a statement is true is to know more than we can tell' (Polanyi 1966, p. 23). In other words, tacit knowledge is complementing and interacting with explicit/coded knowledge. In short, farmers generally acquire habitual routines based on both tacit and explicit knowledge, commonly causing lockins (e.g. Martin and Sunley 2006) within overall path dependent farming practices. A related reasoning would argue that social learning based on many weak connections may in the long- 
term be considered more favorable than few strong connections: the 'strength of weak ties' argument underlying the heterophily theory, bridging micro- and macro scales, and with strength determined by time, emotional intensity, and reciprocity (Granovetter 1973). Over time, network of heterophily may turn into homophily if the members of the network become too similar and characterized by bonding. On the other hand, from the very start working together with a few relatives and friends will foster few and strong relationships, termed as multiplexity (Verbrugge 1979).

Different categories of farmers may make use of dissimilar information networks. Reviewing literature on farmers and the issue of taking environmental actions, Burton (2014) found that younger farmers had higher awareness, making it easier for them to seek information. On the other hand, age was also seen as a proxy for long-term experience, thereby constituting an important resource for information. This was especially warranted for farming practices. Adding to this is the role of education in easing access to information of a particular type, potentially making farmers with formal education linking up more frequently with particular information sources. Burton (2004) argued that fellow farmers are important as sources for information in spite of some studies showing the opposite, explaining this apparent contradiction with an unwillingness to admit looking to other farmers. A similar study in Norway by Orderud and Vogt (2013) showed that protagonist farmers acted as role models for how to do good farming, making the point of differentiating between other farmers in general and a few outstanding ones. This last study also outlined how an institutionalized system of practice-oriented dissemination of information and knowledge played an important role for the process of learning ${ }^{5}$. 
Only few studies in China have addressed information sources among farmers. Weber and Bergmann (2010), studying farmers in two counties of Shandong province, found that beyond one's own experience, farmers basically relied on informal information systems and personal network for their nitrogen management. Neighbors were their main information source, followed by private providers and extension staff, relatives and friends, and media. Jin, Bluemling, and Mol (2015) pointed to the increasing role played by retailers as information sources, due to the absence of an adequate extension service. Pesticide use appeared as a “joint result of retailers' information provision strategies and farmers' trust" (ibid. p. 23), that is, overuse would be a result of either information distortion or lack of trust. Farmers being member of a cooperative did better than others in using right dosages of pesticides. Sun et al. (2012) underlined the role of the agriculture extension service for providing farmers with accurate information on the use of fertilizers and pesticides. More generally, studying environmental knowledge in the metropolitan city of Hong Kong, Cheung et al. (2014) found that traditional media channels played an important role in disseminating information on environmental issues with digital media being more important among the younger generation.

\section{Hypotheses}

The Yuqiao area is characterized by small plots of agricultural land as well as small-scale husbandry. It is reasonable to expect this type of farming to be dominated by multiplexity; that is, friends and kin working together and forming small, tight social groups or networks. The work of Jin, Bluemling, and Mol (2015) indicates the presence of such formations. Multiplexity should facilitate relatively few, strong ties and concomitantly relative few information sources regarding farming and environmental issues, thereby fostering strong tacit knowledge and learning-by-doing. Moreover, relative strong knowledge lock-in as part 
of locally dominated path dependence would be common. However, a different trajectory is also possible: farmers are production oriented and aim at producing large outputs. Over time, this should facilitate reliance on a broader range of information sources due to e.g. the inherent unpredictability of farming (e.g. long time between sowing and harvesting, making doing things at the right time decisive). Accepting the notion that eutrophication is a 'wicked problem' indicates that practicing environmental sustainable farming is posing challenges, thereby also facilitating the presence of social learning and making lock-in less likely.

We generally hypothesize that the segment of farmers with relatively few and strong information sources is dominant among farmers in the Yuqiao area (multiplexity), but we also expect to find a smaller segment of farmers characterized by a broader range of mostly weak information sources due to the existence of other factors (independent variables), such as e.g. social status. In-between those two segments, and in the grey zone of multiplexity, homophily may form. The survey conducted for this research cannot fully discern homophily from heterophily, though. However, we may infer that farmers with a moderate number of information and instruction sources are prone to develop homophily.

More in detail, for environmental values we expect the New Ecological Paradigm (NEP) worldview (Dunlap et al. 2000) to dictate using more information and instruction sources than the Dominant Social Paradigm (DSP) worldview. We expect farmers having a DSP worldview to attach stronger importance to information and instruction from suppliers than farmers having a NEP worldview.

Regarding the farming motive variables ${ }^{6}$, recognition/status may give priority to local information and instruction sources because those sources will confirm recognition in the daily life, but recognition from outside the village/area may also play an important role. On 
the other hand, farmers with environment and/or health motives may give priority to non-local sources.

Situational variables. Of the socio-demographic variables, being a young farmer (age) is expected to foster a broader range of information and instruction sources; stronger priority to non-local information sources; stronger importance to internet; to conceive information on fertilizers as clear and thus not difficult to use correctly; and older farmers will to a larger degree make use of and attach stronger importance to other farmers and in general local information and instruction sources. Long education follows the pattern of younger farmers. Several studies have found females to be more supportive of environmental protection than males (e.g. Chen et al. 2011; Feng and Reisner 2011; Xiao and Hong 2010). Information and instructions on environmental sound farming may be difficult to find. We may thus expect that females make use of more information and instruction sources, including non-local ones.

Regarding socio-economic variables, we expect farmers with high family income, selfreported high social status, and membership in the Communist Party of China (CPC) to foster the use of a broad range of information and instruction sources, as well as giving priority to a wide variety of both local and non-local sources. Presumably, they will more than others favor using internet and suppliers as sources for information. Furthermore, farmers with these characteristics will more easily understand the information on using fertilizers (Xiao, Dunlap, and Hong 2013). Farmers living in villages with high poverty rates will foster an opposite pattern from those of high family income.

Regarding experience, we expect self-reported good farming competence to show a similar pattern as high self-reported social status. The wish to continue farming in the region should foster a broader range of information sources and to a certain degree follow the same pattern 
as self-reported good farming competence. Due to time constraints the residents tending jobs also outside farming are conceived to use fewer information and instruction sources, as well as reporting lower scores on clear instructions and higher scores on difficult to use fertilizers. Psychological variables. Pro- and anti-local social attitudes may also belong to situational variables (experience), but they are essentially socio-psychological based location-specific factors. The same goes for continue living in the area. We expect pro-local social attitudes to foster a favorable view on local information and instruction sources, and the opposite for antilocal social attitudes. The same pattern should appear for the desire to continue living in the region.

\section{Materials and methods}

\section{Study site and the sample}

The survey ${ }^{7}$, conducted in spring 2012, encompassed farmers in 11 villages in the local watershed north of the Yuqiao reservoir ${ }^{8}$. The selection of villages aimed at capturing the span of farmers growing different dominant crops in the area (i.e. wheat, corn, vegetables, and orchards) as well as breeding husbandry (poultry, pigs, and fish farming). The number of respondents in each village varied mainly between 47 and 53, but went down to 39 in the smallest village and up to 60 in the largest. Prior to the statistical analysis 37 of the 545 questionnaires were rejected due to unreliable response patterns. The distribution on age and education was good, though women were overrepresented ${ }^{9}$.

\section{Statistical analysis}

The analysis applies quantitative methodology including descriptive statistics (frequencies and means, and Cronbach alfa and item-total correlations) and multivariate statistical methods 
(linear and categorical regression), using IBM SPSS Version 22. The responses to the questions were constructed as six-point Likert scales. For one part of the analysis, the Likert scales of scores on information and instruction sources were transformed into numerical scales based on number of sources. In addition, the study used categorical regression for assessing the role of individual instruction and information sources.

The dependent variables assessed in this study are: (i) number of information sources, see Table 2; (ii) seven individual information sources, see Table 3; (iii) number of instruction sources; (iv) six individual instruction sources, see Table 4; (v) clear instructions for each of three types of fertilizers - human sewage, manure, and mineral fertilizers, see Table 5; and (vi) difficult to use for each of the three types of fertilizers as listed under the previous point, see.

The independent variables that are assessed in this study regards Barr's $(2007,2008)$ three dimensions: environmental values, situational variables, and psychological factors (Table 6, Annex A).

Hierarchical methods are used in the analysis of both the linear and categorical regression between dependent variables and the sets of independent structural variables as outlined in Model 1 and 2 described below:

Model 1, consisting of only independent structural background variables (e.g. gender, age, education, income, et cetera), is run for all dependent variables (information and instruction sources, clear information, and difficult to use fertilizers).

Model 2 introduces independent variables representing values, situational, and psychological factors. The procedure differed between linear regressions and categorical regressions. For 
linear regressions (Table 2), methods of Stepwise (presenting just statistically significant variables) and Enter were used. For Enter as well as for categorical regressions (Table 3 to 5) the procedure started with all independent variables and then in a backward procedure manually removing variables with low value on the standardized regression coefficient (Beta) and high value on the significance coefficient. The resulting model consists of only statistically significant variables. In addition, the procedure also took into account whether removing the variable would cause a large drop in $R^{2}$, thereby possibly including one or two statistically non-significant independent variables to avoid considerable reductions in $R^{2}$.

The independent variables Continue living and Continue farming under Model 2 are highly correlated (0.592). The regression procedure has thus been conducted separately for each.

\section{Results}

Standardized regression coefficients for significant model variables are given in Tables 2 to 5 . Probability levels of $0.001,0.01,0.05$, and 0.1 are presented by asterisk signs $(* * *, * *, *$, no asterisk, respectively). In addition, variables included in the regression analysis that have a beta coefficient higher than 0.100 and significance lower than 0.200 are presented with plus or minus sign (+/-) in brackets, indicating whether the effect of the independent variable on the dependent variable is positive or negative.

The regression tables present $R^{2}$-values before removing variables. Removing variables from the model will often cause lower $R^{2}$-values, but on the other hand, the beta value and significance of variables explaining the variance will most likely become higher.

Reliability measures (Annex B) show that Cronbach alfa values are generally very good, although slightly less than 0.7 for two variables (Manure fertilizer under Clear Instructions 
and Difficult to Use). The Item-total correlation values are also generally acceptable (above 0.3 and below 0.8 ), with just one variable a little below 0.3 . For the two linear regression models (Total number of information sources and Total number of instruction sources), the Durbin-Watson is acceptable, and the Normal P-P Plot is fitting very well to the linear curve.

\section{Number of information and instruction sources}

The number of information sources used by the farmers and the importance they are given are presented in Table 1. The responses do not confirm the hypothesis that the majority of farmers are characterized by few and strong information and instruction sources (multiplexity). On the contrary, most farmers make use of a large repertoire of sources $(>8)$ for both information and instructions. However, for information regarding farming and environment issues, the overwhelming majority of those with relatively few information sources consider these sources as strong ${ }^{10}$ (very important), whereas this majority is smaller regarding the fertilizer issue. Moreover, the percentage of farmers considering none of the sources as relevant is larger for the fertilizer issue than for the farming and environment issue. Contemplating the homophily category, and anticipating that this category would form among those with 5 to 8 sources, we still see that most farmers make use of more information and instruction sources. 
TABLE 1: Number and importance (weak and strong ${ }^{11}$ ) of information and instruction sources. $\mathrm{N}$ denotes number of respondents in each category.

\begin{tabular}{|c|c|c|c|c|c|c|}
\hline \multirow{3}{*}{$\begin{array}{l}\text { Number of } \\
\text { sources: }\end{array}$} & \multicolumn{6}{|c|}{ Information sources for learning about how to do farming and environment issues (\%) } \\
\hline & \multicolumn{3}{|c|}{ Distribution between number of sources } & \multicolumn{3}{|c|}{ Distribution of importance } \\
\hline & All & Weak & Strong & Weak & Strong & Sum \\
\hline 0 & 2.8 & & & & & \\
\hline 1 to 4 & 15.2 & 9.6 & 19.6 & 24,7 & 75.3 & $100(\mathrm{~N}=77)$ \\
\hline 5 to 8 & 26.4 & 28.8 & 26.0 & 42.5 & 57.5 & $100(\mathrm{~N}=134)$ \\
\hline 9 to 12 & 24.8 & 29.3 & 23.0 & 46.0 & 54.0 & $100(\mathrm{~N}=126)$ \\
\hline 13 to 15 & 30.9 & 32.3 & $31.4^{i}$ & 40.8 & 59.2 & $100(\mathrm{~N}=157)$ \\
\hline Sum & $100(N=508)$ & $100(\mathrm{~N}=198)$ & $100(N=296)$ & 40.1 & 59.9 & $100(N=494)$ \\
\hline \multirow{3}{*}{$\begin{array}{l}\text { Number of } \\
\text { sources: }\end{array}$} & \multicolumn{6}{|c|}{ Instruction sources for using sewage, manure, and mineral fertilizers (\%) } \\
\hline & \multicolumn{3}{|c|}{ Distribution between number of sources } & \multicolumn{3}{|c|}{ Distribution of importance } \\
\hline & All & Weak & Strong & Weak & Strong & Sum \\
\hline 0 & 8.8 & & & & & \\
\hline 1 to 3 & 21.9 & 21.2 & 26.7 & 42.7 & 57.3 & $100(\mathrm{~N}=110)$ \\
\hline 4 to 7 & 35.3 & 41.4 & 36.0 & 52.0 & 48.0 & $100(\mathrm{~N}=177)$ \\
\hline 8 to 10 & 34.1 & 37.4 & 37.3 & 48.5 & 51.5 & $100(\mathrm{~N}=171)$ \\
\hline Sum & $100(\mathrm{~N}=502)$ & $100(\mathrm{~N}=222)$ & $100(\mathrm{~N}=236)$ & 48.5 & 51.5 & $100(N=458)$ \\
\hline
\end{tabular}

Standardized linear regression coefficients for Model 1, based on structural background variables explaining the number of information sources for farming and environment issues

(Table 2), reveals that young age and CPC membership are the main explanatory factors for having a large number of sources. Two additional explanatory variables appear as statistically significant when using the Enter method on Model 2: Those with strong Pro-local social attitudes and those with low scores on the production/economic motive for farming, with the latter one partly aligning with our expectations. In addition, the results show a negative sign on the desire to continue living in the village ${ }^{11}$. It was noteworthy that social status, family income, and jobs outside farming did not appear as explanatory factors.

Turning to instructions for fertilizer use, the linear regression analysis (Table 2) again shows that under Model 1, based on only structural background variables, the younger farmers and CPC membership have a positive impact on the number of instruction sources. These two factors are also important under the two versions of Model 2 (incl. all explanatory factors), 
with age (year of birth) as the clearly most important. There are also indications that jobs outside farming has a negative impact on the number of instruction sources, while social status plays a positive role - which is in line with our expectations.

The main findings are that young farmers and families with CPC memberships are utilizing the largest repertoire of information and instruction sources.

Table 2: Standardized regression coefficients (Beta) for number of information and instruction sources (linear regression)

\begin{tabular}{|c|c|c|c|c|c|c|}
\hline & \multicolumn{3}{|c|}{$\begin{array}{c}\text { Information sources for agriculture and } \\
\text { environment }\end{array}$} & \multicolumn{3}{|c|}{ Instructions sources for using fertilizers } \\
\hline & M-1 enter & M-2 step 2 & M-2 enter & M-1 enter & M-2 Step 3 & M-2 enter \\
\hline \multicolumn{7}{|l|}{ Gender } \\
\hline Year of birth & $0.277^{* * *}$ & $0.283^{* * *}$ & $0.284 * * *$ & $0.304 * * *$ & $0.272^{* * *}$ & $0.337 * * *$ \\
\hline Own education & & & 0.132 & & & \\
\hline Jobs outside farming & & & & -0.109 & & -0.125 \\
\hline \multicolumn{7}{|l|}{ Family income } \\
\hline Social status village & & & & 0.095 & & 0.108 \\
\hline CPC membership & $0.189 * * *$ & $0.191 * *$ & $0.171 * *$ & $0.170 * *$ & $0.198 * *$ & $0.176 * *$ \\
\hline \multicolumn{7}{|l|}{ Village poverty } \\
\hline NEP worldview* & & & $(+)$ & & & \\
\hline \multicolumn{7}{|l|}{ DSP worldview* } \\
\hline Pro-Local social att. & & & $0.139 *$ & & & \\
\hline \multicolumn{7}{|l|}{ Anti-Local social att. } \\
\hline \multicolumn{7}{|l|}{ Continue farming } \\
\hline Continue living & & & -0.123 & & & \\
\hline Motive: prod/econ & & & $-0.127^{*}$ & & & \\
\hline Motive: env/health & & & & & $-0.128 *$ & $-0.142 *$ \\
\hline \multicolumn{7}{|l|}{ Motive: recog/status } \\
\hline \multicolumn{7}{|l|}{ Farming competence } \\
\hline $\mathrm{R}^{2}$ & 0.115 & 0.114 & 0.190 & 0.111 & 0.124 & 0.166 \\
\hline R2 before removals & & & 0.211 & & & 0.175 \\
\hline
\end{tabular}

* NEP and DSP denote New Ecological Paradigm and Dominant Social Paradigm, respectively (see annex A)

\section{Importance of the various sources of information and instructions}

Radio/TV is the most important source of information regarding farming and the environment, followed by suppliers of fertilizers, the village committee, and the internet ${ }^{12}$

(Table 7, Annex B), complying with the findings regarding residents of Hong Kong (Cheung et al. 2014). Of the about 70 percent stating they have acquired instructions in the usage of 
fertilizers, instructions provided by supplier firms, radio/TV, publications, and internet are most common (Table 8, Annex B). This shows that there is an overlap between information and instruction sources.

According to the multiplexity theory, farmers with few information sources should rely more on and give higher priority to fellow farmers for information than other farmers. This holds true for the 17 farmers with one information source, but the picture becomes less clear already for farmers using two information sources, with a mix of local and non-local sources ${ }^{13}$. Consequently, only a few farmers fit perfectly into a multiplexity picture, as the vast majority makes use of a combination of local and non-local sources. Moreover, farmers with more than one information source consider local sources as less important. Nevertheless, with just one or two non-local sources, they may be seen as situated in the grey zone of multiplexity and the bonding of homophily.

In regards to instruction sources for the use of fertilizers, about half of the farmers using only one or two sources took these instructions from non-local sources. The difference in number and importance between information and instruction sources reflects that looking for concrete instructions is not the same as generally looking for information as farmers tend to turn to sources that are more trusted ween seeking instructions.

Table 3 presents results from a categorical regression analysis of 7 out of the 15 information sources used for farming and environmental issues. The selection of sources was mainly based on high average scores, and subsequently on tests and factor analyses to avoid high correlations that would distort the regression statistics. The findings are summarized as follows: 
Farmers with a high self-reported social status give high priority to several sources of information. Also high education and CPC membership are important explanatory factors for several of the seven information sources, although not as consistently as social status.

Farmers having a strong recognition/status motive for farming, and partly also having a prolocal social attitude and a desire to continue farming, lend greater weight to local instruction sources. Holding jobs outside farming has a consistent negative impact on the emphasis given to three of the local sources, and likewise having an anti-local social attitude has a negative effect on the perceived value of two local sources.

Younger farmers, as well as those with high social status and CPC membership, are clearly giving higher priority to internet. Farmers having a DSP worldview and holding a selfreported good farming competence render instead high confidence to the information received from supplier firms (fertilizers et cetera), whereas farmers with an environmental/health motive for farming are more skeptical to the information provided by suppliers.

Table 4 comprises standardized regression coefficients (Beta) for 6 of the 10 instructions sources for the use of fertilizers. The sources were selected using the same criteria as for agriculture and environmental issues. Emphasis given to different sources of instructions differs from information sources. Again this underlines that searching for instructions on a specific problem linked to farming is something else than gathering general information on environmental issues. The main findings are:

Farmers that conceive themselves as having good farming competence give high priority to a larger number of instruction sources (five out of the six, with internet being the exception). For some unclear reason the level of village poverty has an explanatory power as a 
background explanatory factor for the use of four to five of the instruction sources (not for radio/TV).

Strong Pro-local social attitudes explain the priority given to local instruction sources, and the opposite holds for strong Anti-local social attitudes.

Younger farmers and those with CPC membership give high priority to internet for instruction as well as for information. On the other hand, farmers with strong production/economic motives do not lend any weight to instructions from internet nor Radio/TV. 
Table 3: Standardized categorical regression coefficients (Beta) for selected information sources.

\begin{tabular}{|c|c|c|c|c|c|c|c|c|c|c|c|c|}
\hline & \multicolumn{2}{|c|}{ Farmers in village } & \multicolumn{2}{|c|}{ Village committee } & \multicolumn{2}{|c|}{$\begin{array}{c}\text { Noticeboard in } \\
\text { village }\end{array}$} & \multicolumn{2}{|c|}{ Ji county } & \multicolumn{2}{|c|}{ Internet } & \multicolumn{2}{|c|}{$\begin{array}{l}\text { Supplier firms, } \\
\text { fertilizers etc. }\end{array}$} \\
\hline & Model 1 & Model 2 & Model 1 & Model 2 & Model 1 & Model 2 & Model 1 & Model 2 & Model 1 & Model 2 & Model 1 & Model 2 \\
\hline Gender & & & & 0.130 & 0.116 & $0.131^{*}$ & & $0.154^{*}$ & $0.160 * *$ & $0.175^{* *}$ & & \\
\hline Year of birth & & & & & & $0.229 *$ & $0.202^{*}$ & & $0.172 *$ & $0.241^{*}$ & & \\
\hline Own education & & $0.177^{* *}$ & & $0.140^{*}$ & $0.118^{*}$ & & & & $0.117^{*}$ & & $0.134 *$ & $0.142^{*}$ \\
\hline Jobs outside farming & & & -0.164 & -0.163 & $-0.224^{*}$ & -0.192 & $-0.146^{*}$ & $-0.370 * * *$ & & & & \\
\hline \multicolumn{13}{|l|}{ Family income } \\
\hline Social status village & & & 0.151 & & $0.152^{*}$ & $0.219 * * *$ & $0.132^{*}$ & 0.126 & $0.194^{* * *}$ & $0.224 * * *$ & $0.202 * * *$ & $0.167^{*}$ \\
\hline CPC membership & $0.142 *$ & & $0.148^{* *}$ & & $0.130 * * *$ & & & & $0.141^{* * *}$ & $0.228 * * *$ & & $0.154^{* * *}$ \\
\hline Village poverty & $0.118^{*}$ & & & & & & & & & & $0.139 *$ & \\
\hline NEP worldview & & & & $0.160 *$ & & $0.140 *$ & & & & $0.156^{*}$ & & \\
\hline DSP worldview & & & & & & & & & & & & $0.190 *$ \\
\hline Pro-Local social att. & & $0.196 * *$ & & & & $0.135^{*}$ & & & & & & \\
\hline Anti-Local social att. & & -0.126 & & & & & & $-0.163^{*}$ & & & & \\
\hline Continue farming & & & & $0.238^{* *}$ & & $(+)$ & & & & & & \\
\hline Continue living & & & & & & & & & & $(-)$ & & \\
\hline Motive: prod/econ & & & & & & & & & & -0.132 & & \\
\hline Motive: env/health & & & & & & & & $0.220^{*}$ & & & & $-0.215^{* *}$ \\
\hline Motive: recog/status & & $0.368 * * *$ & & $0.243^{*}$ & & $0.179 *$ & & & & & & 0.162 \\
\hline Farming competence & & & & & & & & & & & & $0.249 * * *$ \\
\hline $\mathrm{R}^{2}$ & 0.070 & 0.277 & 0.089 & 0.224 & 0.088 & 0.246 & 0.088 & 0.215 & 0.152 & 0.250 & 0.111 & 0.237 \\
\hline $\mathrm{R}^{2}$ before removals & & 0.276 & & 0.270 & & 0.247 & & 0.232 & & 0.274 & & 0.258 \\
\hline
\end{tabular}


Table 4: Standardized categorical regression coefficients (Beta) for selected instruction sources.

\begin{tabular}{|c|c|c|c|c|c|c|c|c|c|c|c|c|}
\hline & \multicolumn{2}{|c|}{ Other farmers } & \multicolumn{2}{|c|}{ Village committee } & \multicolumn{2}{|c|}{ Ji county } & \multicolumn{2}{|c|}{ Radio/TV } & \multicolumn{2}{|c|}{ Internet } & \multicolumn{2}{|c|}{$\begin{array}{c}\text { Supplier firms, } \\
\text { fertilizers, et cetera }\end{array}$} \\
\hline & Model 1 & Model 2 & Model 1 & Model 2 & Model 1 & Model 2 & Model 1 & Model 2 & Model 1 & Model 2 & Model 1 & Model 2 \\
\hline Gender & 0.105 & $0.175^{*}$ & 0.090 & & $0.141^{*}$ & & $0.131^{*}$ & & $0.132^{*}$ & & & \\
\hline Year of birth & & & & & & 0.168 & $0.206^{*}$ & & $0.222^{*}$ & $0.274^{* *}$ & & \\
\hline Own education & & & $0.143^{*}$ & $0.127 *$ & & $0.172 *$ & 0.123 & $0.216 * * *$ & & & & \\
\hline Jobs outside farming & & & & -0.130 & & & -0.202 & & & & & \\
\hline Family income & & & & & & & & & & 0.120 & & \\
\hline Social status village & $0.166 * * *$ & 0.116 & & & 0.129 & 0.138 & & & $0.147^{*}$ & & & \\
\hline CPC membership & & & & & $0.193 * * *$ & $0.160^{*}$ & $0.160^{*}$ & & $0.150 * * *$ & $0.185^{* * *}$ & & \\
\hline Village poverty & $0.179 * * *$ & $0.187^{* * *}$ & $0.163^{* *}$ & 0.124 & $0.168^{* * *}$ & $0.178^{* * *}$ & & & 0.090 & $0.171^{* * *}$ & $0.128^{*}$ & $0.203^{* *}$ \\
\hline NEP worldview & & $0.149 *$ & & & & & & & & & & \\
\hline DSP worldview & & & & $(+)$ & & & & $0.134^{*}$ & & & & $(+)$ \\
\hline Pro-Local social att. & & 0.138 & & $0.179 * *$ & & & & & & & & $0.147^{*}$ \\
\hline Anti-Local social att. & & & & $-0.142^{*}$ & & & & & & & & \\
\hline Continue farming & & $(+)$ & & & & $(+)$ & & & & $(+)$ & & \\
\hline \multicolumn{13}{|l|}{ Continue living } \\
\hline Motive: production & & & & & & & & $-0.151^{*}$ & & $-0.177^{*}$ & & \\
\hline \multicolumn{13}{|l|}{ Motive: env/health } \\
\hline Motive: Recog/status & & $0.144^{*}$ & & & & 0.161 & & 0.136 & & & & \\
\hline Farming competence & & $0.253^{* * *}$ & & $0.244^{* * *}$ & & $0.198 * *$ & & $0.292 * * *$ & & & & $0.157^{* * *}$ \\
\hline $\mathrm{R}^{2}$ & 0.092 & 0.264 & 0.092 & 0.205 & 0.116 & 0.208 & 0.122 & 0.228 & 0.135 & 0.226 & 0.049 & 0.180 \\
\hline $\mathrm{R}^{2}$ before removals & & 0.271 & & 0.231 & & 0.231 & & 0.210 & & 0.235 & & 0.201 \\
\hline
\end{tabular}




\section{The fertilizer and phosphorus issue}

Most farmers report they have acquired instructions on how much fertilizer should be applied to their fields, and more than half of them report to have received information about how often it needs to be applied (Table 9, Annex C). Most farmers consider the instructions for using mineral fertilizers as clearer than for the use of manure, while the instructions for the use of human sewage is considered most unclear. Moreover, one of five farmers also regards the instructions for using mineral fertilizers as unclear. Likewise, about half of the farmers consider finding the right usage of fertilizers as very difficult; with the application of human sewage and manure considered even more difficult. This means that despite clear instructions for use of fertilizers, a large portion of the farmers still find it difficult to transform the information into practice.

There are unfortunately no consistent governing factors for the notion of having received clear instructions and understanding how to use the three types of fertilizers. Nevertheless, for having received clear instructions (Table 5) we may note that a higher number of instruction sources is governing clear instructions on the use of sewage from households; fellow farmers provide clear instruction regarding how to use sewage from households and manure; while supplier firms are good at explaining how to apply manure and mineral fertilizers. Taken together, the number of instructions sources that are used is generally important for governing the notion of having received clear instructions. On the other hand, the number of information sources does not play any role. 
Table 5: Standardized categorical regression coefficients for Clear Instructions* regarding usage of fertilizers.

\begin{tabular}{|c|c|c|c|c|c|c|}
\hline & \multicolumn{2}{|c|}{ Human Sewage } & \multicolumn{2}{|c|}{ Manure from animals } & \multicolumn{2}{|c|}{ Mineral fertilizers } \\
\hline & Model 1 & Model 2 & Model 1 & Model 2 & Model 1 & Model 2 \\
\hline Gender & & & 0.103 & & & \\
\hline Year of birth & & & $0.267^{* *}$ & & & $0.274 * * *$ \\
\hline \multicolumn{7}{|l|}{ Own education } \\
\hline Jobs outside farming & & 0.158 & & & & \\
\hline Family income & 0.135 & $0.225^{* * *}$ & & & $0.180 * *$ & $0.206^{* * *}$ \\
\hline Social status village & & & $0.132 *$ & & $0.251 * * *$ & $0.181 *$ \\
\hline CPC membership & $0.096 *$ & 0.088 & 0.097 & $0.147^{* * *}$ & & \\
\hline \multicolumn{7}{|l|}{ Village ownership } \\
\hline NEP worldview & & $(-)$ & & & & \\
\hline Continue living & & $0.174^{*}$ & & & & 0.171 \\
\hline Motive: Env/health & & $0.155^{*}$ & & & & \\
\hline Motive: Status/tidy & & $(-)$ & & $-0.195 * *$ & & \\
\hline Farming competence & & $0.188^{* *}$ & & & & $(+)$ \\
\hline Instructions-sources: Fertilizers & & $0.295^{* *}$ & & & & \\
\hline Instruction fertilizers: Farmers & & $0.171^{*}$ & & $0.178^{* *}$ & & \\
\hline Instruction fertilizers: Suppliers & & & & $0.316 * * *$ & & $0.326 * * *$ \\
\hline $\mathrm{R}^{2}$ & 0.063 & 0.346 & 0.107 & 0.320 & 0.123 & 0.344 \\
\hline $\mathrm{R}^{2}$ before removals & & 0.377 & & 0.340 & & 0.339 \\
\hline
\end{tabular}

* Scores on Clear instructions recoded into four categories: value 1, value $2+3$, value 4+5, value 6

This implies that the role of the various instruction sources differ between the three fertilizer types in generating a clear understanding of how to use the fertilizers. It is noteworthy that having received instructions from other farmers regarding how to apply mineral fertilizers contribute to lower the sense of difficulty, whereas the opposite is the case for instructions from suppliers. The regression table for "difficult to use fertilizers" is not included in the text, but we may note that good farming competence supported high scores on the notion of having received clear instructions, but still having the sense of difficulty in understanding how to use sewage from households. This entails that having received clear instructions do not necessarily foster good understanding of how to use the fertilizers. Lastly, it is noteworthy that farmers having a DSP worldview find it more difficult to use different types of fertilizers than farmers having a NEP worldview. 


\section{Discussion and conclusions}

\section{Information and instructions}

Most farmers gather information regarding farming and environmental issues, as well as instructions for the use of fertilizers, from a large selection of sources. This is in contradiction to the common belief that farmers are sticking with the pack, forming multiplex relations. Still, there is a small segment (about 5 percent) of farmers characterized by multiplexity, mostly comprised by farmers above 50 years of age. It is nevertheless likely that also these inward looking farmers are hooked up with the wider information and instruction network through their contacts with fellow farmers in their villages. Bottom line, our analysis lends weight to farming and eutrophication being conceived as a wicked problem (Patterson, Smit, and Bellamy 2013), demanding collaboration as well as cooperation, and possibly facilitating collective action.

The existence of a broad information and instruction network, documented in this study, implies that a necessary condition for social learning is present. Young farmers and those with CPC membership gather information and instructions from the largest number of sources. These categories of farmers have the potential to act as role models, serving as local messengers and liaison due their larger network. In this way they may act and function as focal points for information and instructions. Moreover, many farmers give high priority to several information and instruction sources, inferring a basis for trusting relations which may contradict the findings of Jin, Bluemling, and Mol (2015). In addition, different categories of farmers make use of and give high priority to different information and instruction sources, 
thereby indicating that the local farming community as a whole may be well informed about basic agro-environmental issues.

The analysis presented above has been conducted using Barr's $(2007,2008)$ approach. Figure 1 depicts and integrates the explanatory relationships between the three categories of explanatory factors i.e. environmental values, situational factors, and psychological factors) in governing the farmers' use of information and instruction sources ${ }^{14}$. The figure illuminates several important findings. Having jobs outside farming and partly having anti-local social attitudes spur a weakening of the role of several information and instruction sources. Farmers relying on local information sources are linking positively to pro-local social attitudes and recognition/status motive for farming, and through the sub-group of multiplex farmers there is a link to age (being above 50 years of age), most likely making the last category strong adherents of pro-local social attitudes.

Although there are some linkages between environmental values and the use of information and instruction sources (e.g. that farmers with NEP values use more sources), the effects were modest. Analyzing environmental values and attitudes on the same sample as for this study, Orderud and Vogt (2016) found that the environmental/health and recognition/status motives for farming were positively linked with NEP and DSP worldviews, respectively. This is making the interactions rather complex. For instance, holding an environment/health motive for farming has a negative effect on number of instruction sources used by the farmer, but environment/health also has a positive impact on the NEP worldview, which in turn, has a positive impact on many strong information sources. Likewise, having a recognition/status motive for farming, which is linked positively to DSP, has a positive impact on the emphasis given to local information/instruction sources and thus indirectly on multiplex farming. 
Therefore, farmers are not following any unidirectional path, or trajectory, shielded behind solid walls when it comes to environmental farming practices, but depending on context they may end up in one or the other more or less environmental sound practice. 
Figure 1: Positive (unbroken arrows) and negative (stippled arrows) effects of independent variables on categories of information and instruction sources.

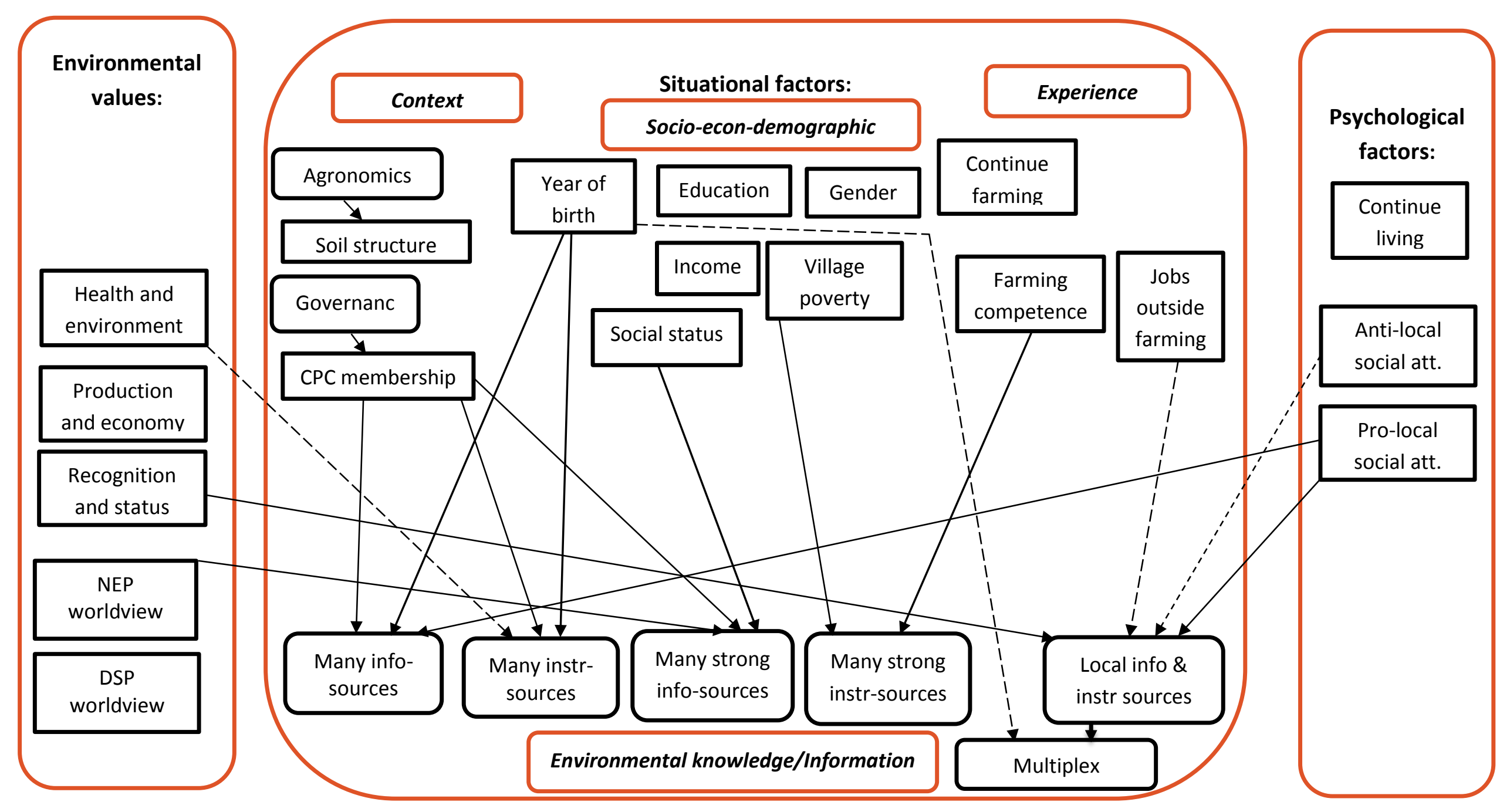





\section{Learning about and using fertilizers, and the context}

We have concluded that there is a firm basis for social learning, and therefore a potential for accommodating profound changes in farming practices, facilitating a shift onto an environmentally sustainable farming trajectory. However, this is not plain sailing because the majority of farmers consider it difficult to know how to use fertilizers, although the majority of farmers have received instructions on applying fertilizers and the majority conceives these instructions as clear ${ }^{15}$.

Considering the apparent serious eutrophication situation in the recipient reservoir, it is important to recognize that just 14 percent of the farmers consider the overall effects of fertilizers as negative and only 21 percent wants to use less mineral fertilizers ${ }^{16}$. Any information or instructions propagating the adverse effects of (excessive) use of mineral fertilizers seem not to have had much impact. On the contrary, farmers appear to be in a lockin of excessive fertilizer use, possibly resulting from most information and instruction sources propagating the advantages of (mineral) fertilizers. We have documented that suppliers are an important information and instruction source, and aligning with Jin, Bluemling, and Mol's (2015) on retailers' role in farmers' excessive use of pesticides, overuse of fertilizers may not come as any surprise. Many farmers are adding heavy loads of fertilizers once or twice a year which easily causes losses of nutrients since the soil in the area has poor nutrient retention capacity (Zhou et al. 2014). They should instead be adding small quantities several times during the growing season. Based on trial-and-errors (experiential learning), farmers may have learnt that they need to add much fertilizer to the soil to sustain high outputs, an experience that eventually has turned into tacit knowledge. This refers to the boxes of Agronomics and Soil structure as sub-dimensions of "Context" under Situational factors in 
Figure 1, indicating that place (context) is crucial. However, space is embedded in time: centuries of meticulously collecting and bringing organic matter, manure and human sewage back to the fields (e.g. Fei 1939; King 1927) has gradually faded during the last 50 years, with China from the mid-1970s eventually entering the age of mineral fertilizer (Smil 2004). The adverse effect of turning to mineral fertilizers, has, depending on context, been an emerging and growing lack of organic matter in the soil that causes the soil to have a poor capacity to hold the nutrients. Thus, the indigenous tacit knowledge on the need for fertilizers, together with messages propagating using mineral fertilizers, may trump any top-down messages from Environmental Protection Agencies on the negative side-effects for the reservoir and water quality of excessive use of fertilizer. This needs to be taken into account when formulating and implementing policy measures.

\section{The governance issue}

Several measures for reducing leaching of phosphorus have been introduced, targeting communities in the Yuqiao watershed; e.g. displacement of villages, decommissioning of fish ponds, establishing constructed wetlands, and recently fencing the reservoir to prohibit locals from using the lake for fishing et cetera. None of them, however, have had its main focus on reducing or improving farmers' use of mineral fertilizers, or handling household sewage and livestock manure ${ }^{17}$.

Our analysis has documented that farmers generally make use of a broad range of information and instruction sources. Moreover, they do not appear as passive "policy-takers", but rather may counter measures introduced by the (local) government, as revealed in interviews by farmers in the same watershed (Tan et al. 2015): the local government's recent policy of "no use, no pollution" reduces the usefulness of the reservoir for locals, thereby provoking 
changes in attitude among locals and concomitantly an emerging "no use, no protection" attitude. Local residents may become reluctant or even hostile to take any pro-environmental action, in spite of having a relatively deep understanding about the importance of environment protection and the harm of their current farming methods.

In effect, what we can observe is a typical rebound effect (Scholz 2011): Farmers may feel provoked by measures taken by the environmental protection agency and resort to taking retributive actions. These actions may however not be in their own long-term interest, and the farmers may gain from contemplating the relationship between themselves and their place of living. How do they want to develop their communities? Their answer to this question is to a certain degree influenced and structured by the information and knowledge network they are part of, with various information-knowledge sources. About 50 percent state they will continue living in the village and another 20 to 25 percent are uncertain about it, indicating a potentially solid fundament for sustaining local communities in the area. The question is how the reflective relationship between local residents' attitude towards the environment and the local government on this issue develops.

Following from the above, and in line with the "muddling through" by local environmental protection officers, reported by Zhou et al (2013), we argue that farmers may better be seen as muddling through messages from different sources and measures implemented by the local Environmental Protection Agency. On their part, local environmental protection officers are trying their best to balance (contradictory) higher-levels policy priorities and possibly carve out a way based on local priorities. Farmers respond to policy measures, based on their farming experience and output aims and economics, but also factors as community development and environmental values are entering the scene. This is not to say that farmers 
are part of the regular governance structure, but to say they still have some leeway for complying with or ignoring measures. Farmers capability of taking counter measures has also been documented in Gong and Zhang's (2017) study of farmers trying to avoid changing from single to double annual cropping of rice, but also that the county government adjusted their strategy to and measures to have more double cropping, again resembling a muddling through patter. Regarding Yuqiao, the muddling through could very well align with Heilmann and Perry's (2011) adaptive governance system and its experimentation under hierarchy. In fact, the watershed has been the object of several pilot experiment research projects (national and international).

\section{Concluding the discussion}

The study of this article has disclosed that there is a firm basis for social learning, and we have found that in particular young farmers and CPC members, but also those with good farming competence, may play a crucial role as mediators in this social learning system. Complementing this is the findings of Orderud et al (2015) that CPC members and selfreported good farming competence, together with farmers having received instruction in the use of phosphorus, are more prone to taking (environmental) action. In short, the necessary information-knowledge fabric for achieving environmentally sound farming is present but may not be sufficient. In order for environmentally sound farming to become part and parcel of the habitus of daily farming practices, the necessary actions obviously have to be made economically and practically feasible. How this may be achieved is a topic moving beyond the scope of this article, demanding a more thorough analysis of policies, the interaction between different political-administrative levels, as well as structural driving forces operating at different scales. 
The main weakness of our study is that we cannot tell for sure whether there are any actual social learning, or whether the learning network has turned into homophily (bonding). This should be addressed in future research. This also means analyzing how social learning is interacting with other types of learning, as experiential learning, revealing the roles of different information channels and categories of farmers and (policy) stakeholders for transforming learning and knowledge into practices of sustainable farming. 


\section{NOTES:}

1 Nutrients are not as such a pollutant, but turn into pollution when appearing in excessive levels causing degradation of water quality and biodiversity.

2 For instance, The Environment Protection Law was issued in 1989 and was amended in 2014; and the Law on Prevention and Control of Water Pollution was introduced in 1984, revised in 1996 and 2008, ultimately resulting in a "Water Pollution Prevention and Control Action Plan” in 2015, engaging 15 ministries and governmental departments.

3 We generally simplify by using information-knowledge, omitting awareness-learning. This is not to claim that learning is less important. On the contrary, learning is the link between information and knowledge.

4 The area hosts around 800000 poultry, 100000 pigs, around 15000 sheep, and around 5000 cattle.

5 This is arranged by the Agricultural Advisory and Experimental Society, based on membership and convening meetings at local farms.

6 These motives are also partly psychological, but we classify them as values because they represent values underlying farming and thereby supplementing the more general values of NEP and DSP.

7 The survey was conducted with the aid of four graduate students from Nankai University, Tianjin. The students received training on beforehand, and together with the responsible researcher, they guided and monitored respondents answering the questionnaire, thereby improving the reliability of the survey.

8 About 100000 people are residents of the area, and there are about 150 villages. 
9 The share of women is 72 percent, still allowing gender to be included in the multivariate analysis.

10 Scores in the range from 1 to 3 are classified as 'weak', whereas scores in the range of 4 to 5 are 'strong'.

11 Apparently, a positive sign on pro-local social attitudes and a negative sign on continue living is contradictory. However, it is quite conceivable that some of the farmers holding the social milieu in high esteem also plan to move: the individual/structural pull factors are stronger than the individual/structural push factors.

12 Today, radio/TV is increasingly broadcasting through internet, but at the time of the survey, this was not the case.

13 Of the 17 farmers with one source, 11 had marked a fellow farmer in the village; of the 12 farmers with two sources, five relied only on local sources; out of the 22 farmers with three sources, four relied solely on local sources. Local sources comprises fellow farmers in village, farmers from other villages in the county village committee, and noticeboard in village.

14 Although the variables continue living and continue farming do not have any direct explanatory power, they are generally included in the regression models due to the fact that removing them very often causes a considerable drop in size of $R^{2}$.

15 One reason for this may be that many households are introducing (quasi-) flush toilets, making the sewage less suitable for being processed into fertilizers.

16 The first question was "Do you think the possible gains of use of phosphorus outweigh the possible negative effects?", with 67 percent consider the overall effect of fertilizers to be positive, 19 percent a balance, and 14 percent negative. The second question was "Would you 
like to use more phosphorus from mineral fertilizers on your fields?", with 40 percent wanting to use more mineral fertilizers, 39 percent not knowing, and 21 percent less.

17 Several years ago there were some programs addressing domestic sewage, but at the time of the 2012 fieldwork, most of them had been abandoned due to the lack of subsequent governmental financial support. 


\section{Literature}

Barr, S. 2007. Factors Influencing Environmental Attitudes and Behaviors: A U.K. Case Study of Household Waste Management. Environment and Behavior 39: 435-73.

Barr, S. 2008. Environment and society - sustainability, policy and the citizen. Aldershot, UK: Ashgate.

Burgess, J., C. M. Harrison, and P. Filius. 1998. Environmental communication and the cultural politics of environmental citizenship. Environment and Planning A 30: 1445-460. Burton, R. J. F. 2004. Reconceptualising the 'behavioral approach' in agricultural studies: a socio-psychological perspective. Journal of Rural Studies 20: 359-71.

Burton, R. J. F. 2014. The influence of farmer demographic characteristics on environmental behavior: A review. Journal of Environmental Management 135: 19-26.

Castells, M. 1996. The information age: economy, society and culture. Volume I: The rise of the network society. Oxford, UK: Blackwell Publishers.

Castells, M. 2010. Information Age Globalisation, Networking, Urbanisation: Reflections on the Spatial Dynamics of the Information Age. Urban Studies 47: 2737-45.

Chen, X., M. N. Peterson, V. Hull, C. Lu, G. D. Lee, D. Hong, and J. Liu. 2011. Effects of attitudinal and sociodemographic factors on pro-environmental behavior in urban China. Environmental Conservation 38: 45-52.

Cheung, L. T. O., L. Fok, E. P. K. Tsang, W. Fang, and H. Y. Tsang. 2014. Understanding residents' environmental knowledge in a metropolitan city of Hong Kong, China. Environmental Education Research 21: 507-24. 
Dunlap, R. E., K. D. van Liere, A. G. Mertic, and R. E. Jones. 2000. Measuring Endorsement of the New Ecological Paradigm: A Revised NEP Scale. Journal of Social Issues 56: 425-42. Fei, H. T. 1939. Farmer life in China. A field study of country life in the Yangtze Valley. London, UK: Kegan Paul, Trench, Trubner \& Co.

Feng, W. and A. Reisner. 2011. Factors influencing private and public environmental protection behaviors: results from a survey of residents in Shaanxi, China. Journal of Environmental Management 92: 429-36.

Gong, W. and Q. F. Zhang. 2017. Betting on the Big: State-Brokered Land Transfers, LargeScale Agricultural Producers, and Rural Policy Implementation. The China Journal 77: 1-26. Granovetter, M. 1973. The strength of weak ties. American Journal of Sociology 78: 1360-80. Gross, A. G. 1994. The Roles of Rhetoric in the Public Understanding of Science. Public Understanding of Science 3: 3-23.

Gu, J., J. Luo, G. I. Orderud. 2015. Social Construction Based on Long-Distance Water Diversion Projects — A Case Study on the Yuqiao Reservoir in Tianjin. Chinese Journal of Urban and Environmental Studies 3: 1-14.

Heilmann, S. and E. J. Perry (eds.). 2011. Mao's Invisible Hand - The Political Foundations of Adaptive Governance in China. Cambridge, MA: Harvard University Press.

Huang, X., D. Zhao, C. G. Brown, Y. Wu, and S. A. Waldron. 2010. Environmental Issues and Policy Priorities in China: A Content Analysis of Government Documents. China: An International Journal, 8 (2): 220-46. 
Ison, R., N. Röling, and D. Watson. 2007. Challenges to science and society in the sustainable management and use of water: investigating the role of social learning. Environmental Science \& Policy 10: 499-511.

Jin, S., B. Bluemling, and A. P. J. Mol. 2015. Information, trust and pesticide overuse: Interactions between retailers and cotton farmers in China. NJAS - Wageningen Journal of Life Sciences 72-73: 23-32.

King, F. H. 1927. Farmers of forty centuries or permanent agriculture in China, Korea and Japan. London, UK: Jonathan Cape.

Kolmuss, A. and J. Agyeman. 2002. Mind the Gap: why do people act environmentally and what are the barriers to pro-environmental behavior? Environmental Education Research. 8: 239-60.

Lieberthal, K. and M. Oksenberg, 1988. Policy Making in China: Leaders, Structures, and Processes. Princeton, NJ: Princeton University Press.

Lindblom, C. 1959. The Science of "Muddling Through". Public Administration Review 19 (2): 79-88.

Martin, R. and P. Sunley. 2006. Path dependence and regional economic evolution. Journal of Economic Geography 6: 395-438.

Mertha, A. C. 2008. China's Water Warriors. Citizen Action and Policy Change. Itacha, NY: Cornell University Press.

Owens, S. 2000. Engaging the public: information and deliberation in environmental policy. Environment and Planning A 32: 1141-48. 
Orderud, G. I. and M. Winsvold. 2012. The role of learning and knowledge in adapting to climate change: a case study of Norwegian municipalities. International Journal of Environmental Studies 69: 946-61.

Orderud, G. I. and R. D. Vogt. 2013. Trans-disciplinarity required in understanding, predicting and dealing with water eutrophication. International Journal of Sustainable Development and World Ecology. 20: 404-15.

Orderud G. I., R. D. Vogt, T. Andersen, and J. Luo. 2015. Explaining and understanding environmental actions in Chinese agriculture - the case of Yuqiao watershed of Tianjin Municipality. International Journal of Sustainable Development and World Ecology 22: 496509.

Orderud G. I. and R. D. Vogt. 2016. Environmental values and attitudes among Chinese farmers. International Journal of Environmental Studies 73: 917-38.

Pahl-Wostl, C. 2009. A conceptual framework for analysing adaptive capacity and multi-level learning processes in resource governance regimes. Global Environmental Change 19: 35465.

Patterson, J. J., C. Smith, and J. Bellamy. 2013. Understanding enabling capacities for managing the 'wicked problem' of nonpoint source water pollution in catchments: A conceptual framework. Journal of Environmental Management 128: 441-52.

Polanyi, M. 1966 [1983]. The Tacit Dimension. Clouchester, MA: Peter Smith.

Qu, J. 2012. The Project System: A New Form of State Governance. Social Sciences in China 33 (4): 28-47. 
Reed, M. S., A. C. Evely, G. Cundill, I. Fazey, J. Glass, A. Laing, J. Newig, B. Parrish, C. Prell, C. Raymond, C. and L. C. Stringer. 2010. What is Social Learning? Ecology and Society 15 (4): r1.

Scholz, R. W. 2011. Environmental Literacy in Science and Society - From Knowledge to Decisions. Cambridge, UK: Cambridge University Press.

Smil, V. 2004. China's Past: China's Future: Energy, Food, Environment. New York, NY: Routledge.

Smith, L. E. D. and K. S. Porter. 2010. Management of catchments for the protection of water resources: drawing on the New York City watershed experience. Regional Environmental Change 10: 311-26.

Sun, B., L. Zhang, L. Yang, F. Zhang, D. Norse, and Z. Zhu. 2012. Agricultural Non-Point Source Pollution in China: Causes and Mitigation Measures. Ambio 41: 370-379.

Tan, H., J. Luo, G. I. Orderud, Y. Zheng, and J. Pan. 2015. The Pollution Caused by Protection: The Unintended Consequences of the Local Governance of the Urban Drinking Water Source Protection in Tianjin, China. Chinese Journal of Urban and Environmental Studies 3: 1550025 .

Teets, J.C. 2013. Let Many Civil Societies Bloom: The Rise of Consultative Authoritarianism in China. The China Quarterly 213: 19-38.

Verbrugge, L. M. 1979. Multiplexity in adult friendship. Social Forces 57: 1286-1309.

Weber, D. and H. Bergmann. 2010. The capability of personal values and guanxi to reduce negative external effects of Chinese agriculture, paper presented for the EAAE seminar 
"External Cost of Farming Activities: Economic Evaluation, Environmental Repercussions and Regulatory Framework”, Greece, September 2010.

Xiao, C. and D. Hong. 2010. Gender differences in environmental behaviors in China. Environment and Population 32: 88-104.

Xiao, C., R. E. Dunlap, and D. Hong. 2013. The nature and bases of environmental concern among Chinese Citizens. Social Science Quarterly 94: 672-90.

Zhou, X., H. Lian, L. Ortolano, and Y. Ye. 2013. A Behavioral Model of "Muddling Through" in the Chinese Bureaucracy: The Case of Environmental Protection. The China Journal 70: 120-47.

Zhou, B, R. D. Vogt, C. Xu, X. Lu, H. Xu, J. P. Bishnu, and L. Zhu. 2014. Establishment and validation of an amended phosphorus index: refined phosphorus loss assessment of an agriculture Watershed in Northern China. Water Air Soil Pollution 225: 429-36.

Zhou, B. 2016. Assessments through field studies, experiments and modelling of potential risk for phosphorus loss from an agricultural watershed. Oslo, NO: University of Oslo. 


\section{Annex A: Independent variable - definitions and loadings.}

Table 6: Variable definitions.

\begin{tabular}{|c|c|c|}
\hline Variable & Definition of variable & Type \\
\hline Gender & 1: females $(72.0 \%) ; 2$ : males $(28.0 \%)(\mathrm{N}=496)$ & Nominal \\
\hline Year of birth & Years; e.g. 1951-1952-1953, et cetera & Numerical \\
\hline Own education & $\begin{array}{l}\text { 1: No formal (7.3\%); 2: Primary (18.9\%); 3: Secondary (47.6\%); 4: High } \\
\text { school (20.3\%); 5: College/university (5.9\%) }(\mathrm{N}=454)\end{array}$ & Ordinal \\
\hline $\begin{array}{l}\text { Jobs outside } \\
\text { farming }\end{array}$ & $\begin{array}{l}\text { 1: Only farming (33.8\%); } 2 \text { : farming and want to work outside (26.9\%); 3: } \\
\text { Working outside farming }(39.3 \%)(\mathrm{N}=494)\end{array}$ & Ordinal \\
\hline Family income & Total income for all family members & Numerical \\
\hline $\begin{array}{l}\text { Social status } \\
\text { village }\end{array}$ & $\begin{array}{l}\text { 1: Bottom (17.3\%); 2: Middle-low (18.0\%); 3: Middle-high }(20.0 \%) ; 4: \\
\text { Close to top }(16.4 \%) ; 5: \text { Top }(28.3 \%)(N=434)\end{array}$ & Ordinal \\
\hline CPC membership & $\begin{array}{l}\text { 1: none }(74.4 \%) ; 2 \text { : One or both parents }(19.9 \%) ; 3 \text { : Husband or wife } \\
(3.9 \%) ; 4: \text { husband or wife plus one/both parents }(1.0 \%) ; 5 ; \\
\text { Husband/wife plus one/both parents }(0.8 \%)(\mathrm{N}=508)\end{array}$ & Ordinal \\
\hline $\begin{array}{l}\text { Village poverty } \\
\text { rate }\end{array}$ & $\begin{array}{l}\text { Percentage of respondent's family in each village below } 60 \text { per cent of } \\
\text { median family income }\end{array}$ & Numerical \\
\hline $\begin{array}{l}\text { Farming } \\
\text { competence }\end{array}$ & $\begin{array}{l}\text { "How do you consider your competence in farming?" Score on a six point } \\
\text { scale. }\end{array}$ & Ordinal \\
\hline $\begin{array}{l}\text { Instructions P- } \\
\text { use }\end{array}$ & $\begin{array}{l}\text { Sum of marks on instructions for when to use, how often use, and how } \\
\text { much sewage, manure, and mineral fertilizer to use (yes=1, no=0). }\end{array}$ & Numerical \\
\hline Info-sources & Sum of information sources on agriculture and environmental. 15 sources & Numerical \\
\hline $\begin{array}{l}\text { Instruction- } \\
\text { sources }\end{array}$ & $\begin{array}{l}\text { Sum of instruction sources on instruction on fertilizer use. } 10 \text { different } \\
\text { sources. }\end{array}$ & Numerical \\
\hline NEP worldview & $\begin{array}{l}\text { Average score on four pro-environmental statements, based on five point } \\
\text { scale }\end{array}$ & Numerical \\
\hline DSP worldview & Average score on four pro-human statements, based on five point scale & Numerical \\
\hline $\begin{array}{l}\text { Pro-Local social } \\
\text { attitudes }\end{array}$ & $\begin{array}{l}\text { Average score on 'good and stable social relations', and 'asset that } \\
\text { everyone helps each other when needed', based on six point scale }\end{array}$ & Numerical \\
\hline $\begin{array}{l}\text { Anti-Local social } \\
\text { attitudes }\end{array}$ & $\begin{array}{l}\text { Average score on 'Gossip is everywhere and is a bad feature', and 'The } \\
\text { life here is rather boring', based on six point scale }\end{array}$ & Numerical \\
\hline $\begin{array}{l}\text { Farming motive: } \\
\text { production/econ. }\end{array}$ & $\begin{array}{l}\text { Average score on production/economy as motives for farming. Six point } \\
\text { scale. }\end{array}$ & Numerical \\
\hline $\begin{array}{l}\text { Farming motive: } \\
\text { Health/Environ. }\end{array}$ & $\begin{array}{l}\text { Average score on health/environment as motives for farming. Six point } \\
\text { scale. }\end{array}$ & Numerical \\
\hline $\begin{array}{l}\text { Farming motive: } \\
\text { Tidy/Status }\end{array}$ & $\begin{array}{l}\text { Average score on tidiness/status of farmers as features of farming. Six } \\
\text { point scale }\end{array}$ & Numerical \\
\hline Continue living & $\begin{array}{l}\text { For how long do you want to live in the village? } 1=\text { rest of life; } 2=\text { not rest } \\
\text { of life. }\end{array}$ & Ordinal \\
\hline Continue farming & $\begin{array}{l}\text { For how long do you think you will live in village, if you can decide by } \\
\text { yourself? } 1=\text { rest of life } 2=\text { not rest of life. }\end{array}$ & Ordinal \\
\hline $\begin{array}{l}10 \text { instruction } \\
\text { sources: }\end{array}$ & $\begin{array}{l}\text { (i) other individual farmers; (ii) village committee (iii) Ji County agencies; } \\
\text { (iv) Tianjin Municipality agencies; (v) Farmers' association; (vi) Other } \\
\text { professional associations; (vii) Supplier firms; (viii) Publications; (ix) } \\
\text { Radio/TV; and ( } x \text { ) Internet. Six point scale transformed into four point } \\
\text { scale for each of ten instruction sources: }(1=1,2=2,3+4+5=3,6=4)\end{array}$ & Ordinal \\
\hline
\end{tabular}




\section{Annex B: Additional tables for information and instruction sources}

Table 7: Information sources for agriculture and environmental issues.

\begin{tabular}{|c|c|c|c|c|c|c|c|c|}
\hline \multirow[t]{2}{*}{15} & \multicolumn{8}{|c|}{$\begin{array}{l}\text { What are your information sources for learning about how to do farming and environmental issues, and } \\
\text { how important are they for your farming (or how satisfied are you with their information)? } \\
\text { where } 1=\text { not relevant, and } 2 \text { = very small importance and } 6 \text { = very high importance }\end{array}$} \\
\hline & Face-to-face communication among farmers & 1 & 2 & 3 & 4 & 5 & 6 & Mean \\
\hline 493 & Fellow farmers in the village & 39.6 & 18.1 & 3.4 & 3.4 & 5.5 & 30.0 & 3.07 \\
\hline 475 & Farmers from other villages in the county & 31.6 & 21.7 & 6.1 & 6.7 & 5.3 & 28.6 & 3.18 \\
\hline \multirow[t]{2}{*}{457} & Farmers from other places & 43.8 & 19.0 & 5,9 & 3.1 & 7.0 & 21.2 & 2.74 \\
\hline & Information and training organised by: & & & & & & & \\
\hline 457 & Village committee & 27.1 & 17.5 & 6.1 & 4.6 & 5.5 & 39.2 & 3.61 \\
\hline 459 & Ji county & 36.5 & 14.5 & 4.9 & 6.3 & 5.4 & 32.4 & 3.30 \\
\hline 447 & Tianjin Municipality & 36.1 & 13.8 & 4.7 & 6.2 & 5.1 & 33.5 & 3.27 \\
\hline 456 & "Farmer's association" & 37.1 & 17.3 & 4.8 & 7.5 & 5.9 & 27.4 & 3.10 \\
\hline \multirow[t]{2}{*}{452} & Professional organizations & 40.7 & 15.9 & 5.1 & 5.1 & 6.9 & 26.3 & 3.00 \\
\hline & Information and publications: & & & & & & & \\
\hline 439 & Notice board in the village & 34.6 & 20.3 & 4.3 & 7.3 & 3.6 & 29.8 & 3.15 \\
\hline 448 & Agriculture magazines and journals & 28.3 & 21.2 & 6.3 & 6.9 & 7.8 & 29.5 & 3.33 \\
\hline 457 & Regular newspapers & 29.1 & 20.1 & 7.2 & 6.8 & 6.1 & 30.6 & 3.33 \\
\hline 468 & Radio and television & 20.3 & 13.9 & 6.2 & 5.3 & 7.3 & 47.0 & 4.06 \\
\hline \multirow[t]{2}{*}{448} & Internet & 29.5 & 17.9 & 4.9 & 5.6 & 6.9 & 35.3 & 3.48 \\
\hline & Other information contacts: & & & & & & & \\
\hline 447 & Suppliers/vendors of machinery and tools & 30.9 & 19.7 & 3.8 & 5.8 & 8.9 & 30.9 & 3.35 \\
\hline 459 & Suppliers/vendors of fertilizers, etc. & 25.3 & 13.7 & 5.2 & 6.3 & 7.2 & 42.3 & 3.83 \\
\hline
\end{tabular}

For all sources, the values of Cronbach alfa if item deleted are between 0.900 and 0.915 , and almost all Corrected item-total correlation values are above 0.500, except for Fellow farmers in the village (0.383) and Farmers from other places $(0.483)$.

Table 8: Instruction sources for the use of sewage, manure, and mineral fertilizers.

\begin{tabular}{|c|l|c|c|c|c|c|c|c|}
\hline \multirow{2}{*}{$\mathbf{N}$} & \multicolumn{7}{l}{$\begin{array}{l}\text { lrom who have you got any instructions for use of sewage, manure and mineral fertilizers, and how } \\
\text { important do you consider the different sources to be? } \\
\mathbf{1}=\text { not relevant, and 2 = very small importance and 6 = very high importance }\end{array}$} \\
\cline { 2 - 10 } & & $\mathbf{1}$ & $\mathbf{2}$ & $\mathbf{3}$ & $\mathbf{4}$ & $\mathbf{5}$ & $\mathbf{6}$ & Mean \\
\hline 510 & Other individual farmers & 31.6 & 25.1 & 3.5 & 6.3 & 4.3 & 29.2 & $\mathbf{3 . 1 4}$ \\
\hline 489 & Village committee & 38.4 & 18.0 & 7.4 & 6.7 & 5.5 & 23.9 & 2.95 \\
\hline 479 & Ji county agencies & 44.9 & 20.5 & 5.4 & 4.2 & 4.4 & 20.7 & 2.65 \\
\hline 466 & Tianjin municipality agencies & 52.1 & 15.7 & 3.4 & 4.1 & 5.6 & 19.1 & 2.53 \\
\hline 469 & Farmer's association & 50.3 & 18.6 & 3.0 & 4.7 & 4.7 & 18.6 & 2.51 \\
\hline 455 & Other professional organizations & 45.9 & 16.0 & 6.2 & 5.7 & 6.2 & 20.0 & 2.70 \\
\hline 478 & Supplier firms & 22.6 & 22.6 & 6.1 & 6.3 & 8.6 & 33.9 & $\mathbf{3 . 5 7}$ \\
\hline 472 & Publications & 29.7 & 18.2 & 5.5 & 8.3 & 6.6 & 31.8 & $\mathbf{3 . 3 9}$ \\
\hline 489 & Radio and tv & 25.8 & 18.8 & 6.1 & 9.0 & 5.3 & 35.0 & $\mathbf{3 . 5 4}$ \\
\hline 476 & Internet & 37.8 & 14.3 & 3.8 & 6.3 & 6.7 & 31.1 & $\mathbf{3 . 2 3}$ \\
\hline
\end{tabular}

The values of Cronbach alfa if item deleted are between 0.880 and 0.900 , and almost all

Corrected item-total correlation values are above 0.500 , except for Other individual farmers (.433). 


\section{Annex C: Additional table for learning about and gains/usage of fertilizers}

Table 9: Share of farmers that had received instruction for the usage of fertilizers, how clear instructions are, and how difficult it is to use fertilizers.

\begin{tabular}{|c|c|c|c|c|c|c|c|c|}
\hline \multicolumn{7}{|c|}{ Have you got any instructions about: } & $\mathrm{N}$ & $\%$ \\
\hline \multicolumn{7}{|c|}{ When to use sewage, manure, and mineral fertilizer } & 319 & 71.5 \\
\hline \multicolumn{7}{|c|}{ How often to use sewage, manure, and mineral fertilizer } & 256 & 57.4 \\
\hline \multicolumn{7}{|c|}{ How much sewage, manure, and mineral fertilizer to use under different conditions } & 319 & 71.5 \\
\hline \multicolumn{7}{|c|}{$\mathrm{N}$ (those who got instructions on one or more issues) } & 446 & \\
\hline \multicolumn{9}{|c|}{$\begin{array}{l}\text { In general, how clear are the instructions you receive for use of sewage, manure and mineral fertilizers? } \\
\text { where } 1=\text { not clear at all, and } 2=\text { very little clear and } 6=100 \text { per cent clear }\end{array}$} \\
\hline & $\mathrm{N}:$ & 1 & 2 & 3 & 4 & 5 & 6 & Mean \\
\hline Sewage from households & 494 & 29.4 & 6.5 & 6.5 & 6.1 & 7.1 & 44.5 & 3.89 \\
\hline Manure from animals & 490 & 23.3 & 6.1 & 4.3 & 8.8 & 9.4 & 48.2 & 4.19 \\
\hline Mineral fertilizers & 496 & 21.0 & 3.6 & 4.0 & 5.4 & 8.5 & 57.5 & 4.49 \\
\hline \multicolumn{9}{|c|}{$\begin{array}{l}\text { In general, how difficult do you think it is to decide how much of sewage, manure and mineral fertilizers to } \\
\text { use when? where } 1 \text { = very big challenge, and } 6 \text { = very easy }\end{array}$} \\
\hline & $\mathrm{N}:$ & 1 & 2 & 3 & 4 & 5 & 6 & Mean \\
\hline Sewage from households & 496 & 41.9 & 7.7 & 7.9 & 6.3 & 7.3 & 29.0 & 3.16 \\
\hline Manure from animals & 491 & 40.5 & 6.5 & 5.7 & 10.2 & 6.7 & 30.3 & 3.27 \\
\hline Mineral fertilizers & 500 & 37.4 & 7.4 & 5.2 & 7.6 & 7.0 & 35.4 & 3.46 \\
\hline
\end{tabular}




\begin{abstract}
About 20 percent of those who have marked 14 and 15 information sources have marked top score for all sources. It is possible that these respondents have been making marks on 'autopilot', but there are no serious bias in gender, education, age, self-reported social status, and CPC membership among 30 respondents in this group.
\end{abstract}

